\title{
The Circle of Innovation: You Can't Shrink Your Way to Greatness Book Review
}

\author{
Arooj Zeb \\ PhD Scholar Islamia College, Peshawar \\ arooj_zeb@hotmail.com \\ Dr. Anjum Ihsan \\ Assistant Professor Islamia College, Peshawar \\ searchanjum@yahoo.com
}

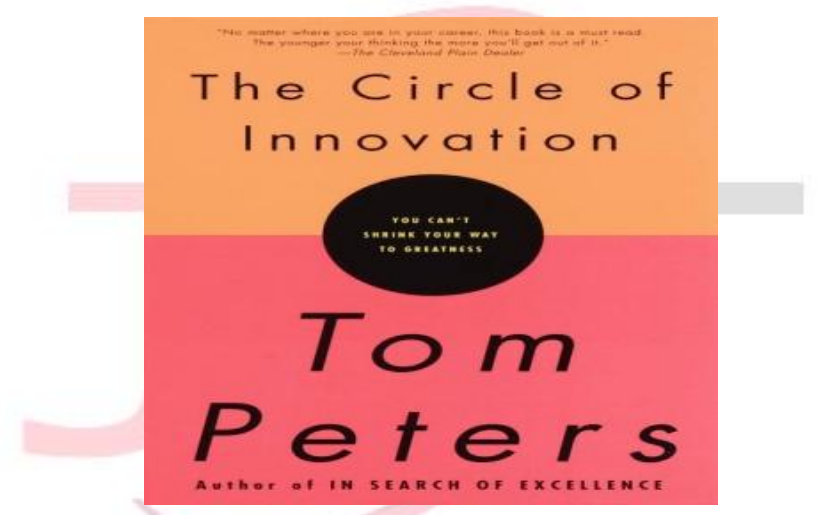

Author: Thomas J. Peters

Publisher: Vintage Books

Number of Pages: 518 pages

Year of Publication: 1999

Language: English

\section{General Overview}

The book "Circles of Innovation" is written by Tom Peters who is called as the father of branding and a business guru. In this book Tom Peters has given us 15 discrete ideas that logically, systematically and coherently add up to the "one big idea" i.e. Innovation. Through 400 seminars in 47 states and 22 countries in five years, Peters has refined and reinvented his views on innovation. The whole idea of this book is either to be innovative or die. This book is a blend of thoughts, quotes and exclamation points which are very inspiring and thought provoking for the readers. Practical examples of successful businesses have been given which focus on innovation. This book is very inspiring as it has got blog graphics, facts and figures that sources range from Martha Steward to Bill Gates. This book is very helpful for those who want to know about how to bring innovation in the organization. The Circle of Innovation is for all those who run a business of any size; from a six-person department to a large business having 500 plus 
employees, it empowers the readers to transform their organizations by following the useful tips of innovation mentioned in this book.

"No matter where you are in your career, this book is a must read. The younger your thinking, the more you'll get out of it."

\section{Chapter by Chapter Analysis and Summary \\ Chapter 1: Distance Is Dead}

\section{The Cleveland Plain Dealer}

Peters is of the view that distance is a goner! And we all are now easily connected to one another. The world has now become a "Global Mall". We should not call it a global village as village is too big. We all are next-door neighbors due to the death of distance among the people in all parts of the world. He further adds that it is the age of Brain ware where the people who lift things are considered to be the new parasites. All people in the modern world value from this "Brainware"! Bill Gates, the richest man in the world was once a nerd but due to his brainware, all are valuing him. Incrementalism is innovation's worst enemy.

\section{Chapter 2: Destruction Is Cool}

The big idea of this chapter is that it's an easy task to kill or destroy an organization than to change it. Destruction is Job number 1. Tom Peters is of the view that the people who think synergy is a powerful tool are wrong. Synergy is actually a snare and a delusion. He quotes Peters Job; the CEO of Reuters who thinks that there is a difference between acquisition (about buying a market share) and new market creation.

Company should acquire talent and use it to spark a new and innovative business. This talent might be new idea, people and companies. It's the age of Talent Based Enterprise and the talent doesn't mean "worker" or "employee". It's a core strategic competence.

Another point being raised by the author in this chapter is of "Waste \& Inefficiency Rules" which means that waste is the byproduct of number of failures. The leader of anything was once believed to be a steward but now steward is a destroyer. CEO (Chief Executive Officer) has now become a CDO i-e Chief Destruction Officer.

\section{Chapter 3: "you can not live without an eraser"}

In this chapter Tom Peters is of the view that most of companies want to innovate themselves or their products but they don't/ can't forget the old ideas. For such companies, an eraser is needed to forget the old ideas and only then, they can bring innovation.

\section{Forgetting--not learning--is the highest art.}

One needs to be decisive, quick and breathtaking to reinvent himself. Tom Peters has given examples of Microsoft, Banana Republic and others who re-invented themselves by forgetting old ideas. Not to focus on forgetting is a mistake for an organization's division, units and for itself as a whole. Micheal Schrage, an author and technology maven believes that "effective prototyping" may be the most valuable core 
competence for an innovative organization. Competitors take several months to do the same. Prototype companies are the ones that are always open to new ideas and experiments.

3Fs are also explained by Tom Peters which are: "Fail.Forward. Fast". Failure is the only precursor to big success. Mistakes are to be encouraged. Organizations that fail should not get dishearten. After failure, there comes a success. In an organization the important person is the one who disagrees with his boss. Tom Peters also talks about Silicon Valley Test and every company should try it because it has got 10 traits and in this way a company knows where it stands.

\section{Chapter 4: We Are All Michelangelos}

The main idea that Peters is giving in this chapter is that employees in businesses are considered to be business persons and free agents. Leaders should treat them as a bona fide business unit of one. He gives example of Ritz Carlton Hotel (Winner of a Malcolm Baldrige National Quality Award) and Lakeland Regional Medical Center (RMC) who work as a business unit and are quite successful. All the people in an organization can and must learn to be business people. It businesses, employees are merely empowered. They all should learn the great game of business. Turn every job into a business, every person into a business person, and business unit of one.

\section{Innovation is about Michelangelo}

It takes trust to lead an organization of business persons. Trust should be on the top of the agenda and it should be treated as a hard issue. Coaching and directing someone are actually about innovation, originality and freshness. Peters is of the view that coaching and directing is about loose and tight. It helps every employee to disclose his own greatness. The crux of this chapter is the "decentralized individual" who should be treated as full-fledged business person.

\section{Chapter 5: Welcome To The White Collar Revolution}

In this chapter, Tom Peters says that time has gone when we largely ignored white collar productivity. It's an era of White Collar Revolution. 58.6 out of every 60 of people in good organizations are at big risk. They are like excess baggage. So it is the need of time that every person in organization performs and makes a measureable difference or else leaves an organization. Make a list of priorities and get them on the day's agenda and make every day count. One needs to make a choice about his/her profession or die (professionally). It's the choice of the person that really matters in the end.

Peters also mentions about power in this chapter. He says that people (male or female) who succeed are those who go for power and grab it even when it's inappropriate. One may lead to the success even having little or no formal authority. He gives the example of Mohandas Gandhi who did significant accomplishment by creating the largest democracy in the world by having no formal authority.

A concept called as PBE (Personal Brand Equity) has been introduced by Tom Peters in this chapter. He is of the views that think of you as a "BRAND" and work on it. He gives a list that helps to think about one's own brand equity. 


\section{Chapter 6: All Value Comes From The Professional Services}

In this chapter, the emphasis has been given on the following points.

\section{All in the professional services}

Tom Peters has suggested that we should consider transforming our departments, our unit into a professional service firm. The formal professional service firm people (Purchasing department, HR department, Logistics, Marketing department) work on improvement revolution.

\section{Professional Service Firm Conversion Kit (PSF 1.0)}

Tom Peters has given few hints regarding how to make your organization as a professional service firm. The points are as follows:

1. Think INC: Don't think yourself as the manager of purchasing rather you need to transform yourself into managing partner of purchasing Inc which means a fully fledged professional service firm.

2. Think client: PSFs always think about their clients and work for them.

3. Visit enemy client Try to do work in professional way which creates a good and lasting impact on everyone.

4. Turn every job into a project: In PSFs, focus is always on the development and execution of projects. Tasks are made related to the project and scheduling is done to complete them on time.

5. Put together a Current Project List (CPL): Make a list of projects that you want to do. PSFs have such lists.

6. Conduct a weekly current project review: PSFs always conduct a weekly current project review in order to make sure that they are on the planner and working accordingly and milestones are completed on time.

7. Think portfolio quality: PSFs is about project portfolio and its increased quality. Project portfolio quality $=$ Life

8. Do whatever it takes: Being a PSF, it is a duty of everyone to help others in a crunch no matter how busy one is. The project team is meant to do whatever it takes it to lead its firm on the top.

9. Transfer your skills to clients: PS Excellence $=$ Teaching/Transferring Excellence

10. Include the client on every project team: In every project, one needs to include the client in every project team so that he gains learning and experience

11. Bring in outsiders: In order to make your firm a PSF, don't rely on your workers only, bring in outsiders and utilize their experience and skills. They should be involved with many projects.

12. Think Marketing: Partners in PSF are marketers so begin in the staff department to think like marketers.

13. Think research and development: PSFs try to make strong their R\&D department as the whole firm depends on it. 
14. Devote a large share of gross revenues to knowledge development: such as ongoing advertising campaign that features your skills and strengths.

15. Establish clear and tough incentives: The main idea is that sharing is as important as project stuff.

16. Train! Train! Train! Train your employees as it is the need of time in professional world.

17. Train in project creation: Train everyone to turn assignment into project.

18. Train in problem solving: Train employees to solve ambiguous situations and use a distinctive approach to solve problems.

19. Train in implementation: Train employees to implement the plan into action.

20. Challenge!: You need to cope with all the challenges effectively.

21. Survive or Go: The bottom-line is that up or out: Either survive and thrive or way you go!

22. Be great: PSFs are great in everything in maintaining local/regional national/global reputation.

23. Think wow: PSFs as a matter of course thinks wow!

\section{The 5 Ps of PSF 1.0}

Tom Peters has given 5 Ps of a Professional Service Firm which are as follows:

\section{The project creation kit (PC 1.0)}

1. First of all you need to begin what you are doing now. Projects are time bound outcomes. Projects results in products that are measureable.

2. You need to know about the milestones (finite benchmarks) of a project. When one milestone is completed, go to the next.

3. Effective client involvement is must in any project. You need to be in constant contact with your client.

4. You need to get ready to face the risks and challenges in a project.

The bottom line of the whole chapter is to become a Value Added Project Freak by using PSF 1.0/PC1.0 and the white collar Robots are coming.

\section{Chapter 7: The Intermediary Is Doomed}

Customers are the ones who run the organization. You need to empower your customer. The bottom-line is that the customers are the key players. They are like the driver of your car and you hand them keys to drive your car (organization).In this chapter Tom Peters says that a concept of "determination" is being followed in most of the successful organizations which are cutting out the middle processes. The layers of intermediary in the supplier producer buyer chain are now removed."FLAT organizations" are the result of disintermediation. The organizations we knew are disappearing and they are losing their shape and substance.

\section{Big idea: Small = Big}

A small organization can do a very big task even with only a handful of people. In short, the intermediary is dying! The friction free game is all about uniting the best talent in any organization to take advantage of market opportunities. 


\section{Chapter 8: The System Is The Solution}

In this chapter Tom Peters has raised a point that Innovation comes in an organization where there is a strong and efficient system. System is like an art which the leader must have. Systems are considered to be of increased importance in an organization. System is an artist's work. Great systems are about Art, beauty, grace and clarity. Innovative companies are always known by their systems, forms, policies and procedures.

\section{Innovation $=$ Beautiful system}

Beautiful systems are the result of graceful language- a language which is plain and amusing and memorable. We know the social side of system and focus on technology i-e intranet, internet, and virtual organizations. They constitute only 5\% of system. $95 \%$ of system is made up of sociology - psychology. It's a people game.

\section{System stuff $=$ People stuff $=$ Real "Hard" stuff}

Department of engineering should be replaced by department of beauty. He has given the example of Southwest Airlines which is a system company and which has staffs of 21000 who is passionately focused on well being of 25 million passengers, moving large number of people efficiently from one place to another.

\section{Chapter 9: Create Waves Of Lust}

In this chapter Tom Peters says that innovation comes in an organization by creating waves of lust. Those who really make a difference invent whole new market, a new way of doing business. We see "sameness" in the products which look/feel/taste/compute about the same. What is considered new today is actually tomorrows (or tonights) copycat target. That is why say no to commoditization. Commoditization isn't inevitable. What we consider "right" is actually "ordinary"

Create waves of lust by:

\section{Winners are the actually re-inventors}

- Re-inventing yourself.

- Fulfill even the unexpected wishes of customers.

- When you believe you can be special in today's world/marketplace.

- Bring quality in yourself

$$
\text { Quality }=\text { Goodness }+ \text { Entertainment }+ \text { Fun }
$$

The customer is a "rear-view mirror", not a guide to the future. An increasing part of leader's role in a crowded market place is to push his customer towards place where they didn't know they wished to venture.

\section{Chapter 10: Tommy Hilfiger Knows}

The bottom line of this chapter is that innovation comes from branding. Most of the professional services firms are "Branding Themselves". Even the smallest firms can learn from Intel, NIKE, and Tommy Hilfiger that brand loyalty is not dead. Branding is possible even in crowded market. In an overcrowded market, product/service distinction alone is not enough. In such markets, branding is more important than ever. Tom Peters defines branding as "it's nothing more than creating a distinct personality and telling the world about it, by hook or by crook". You need to spend on advertising and making sure 
that your message focuses on a distinct look of yours. Organizations should start branding on day 1 . They should love and live their brand as Tom Hilfiger did it from scratch. Their garments have got one button hole which is ringed with bright green embroidery. Tom Peters has identified a way through which branding can be done. "Marketing Aesthetics", It refers to marketing of sensory experiences in brand output that contributes to the brand's identity. One needs to manage this aesthetic experience in order to do branding.

\section{Innovation $=$ Branding Mania}

\section{Chapter 11: Become A Connoisseur Of Talent}

An organization should be a talent based enterprise which demands an obsession with talent. Tom Peters is of the view that all great successes come from the functional and crazy people who are few in number. The leaders of great group love talent and they are always desperate regarding where to find talent. They have fire in their eyes and willingness to acknowledge in the recruiting process. Most of the organizations now prefer inexperienced and young staff to come in the organization to lead the organization to the success. Talent based enterprises work to gather great people to achieve great stuff. They hire for attitude, intelligence, talent, diversity and train for skill and whatever. Good ideas come from differences and one can maximize differences by mix ages, culture i-e diversity. Creativity comes from diversity. He also identifies different "Talent Renewal Kit" whose main purpose is to formally renew the investment plan and talent renewal can be done systematically and strategically.

\section{Chapter 12: It's A Woman's World}

\section{Innovation $=$ Talent Based Enterprise}

The main idea given by Tom Peters in this chapter is that Corporates need to re-invent themselves by taking advantage of the opportunity No.1 i.e. women. There are so many opportunities available to enterprise. The only way to deal with such issues/opportunities is to have women in position throughout the enterprise. Women are now opportunity No.1. He is of the view that American women are the largest National Economy on earth. The total of women owned businesses is largely 8 Million. He has also given reference to the study conducted by Lawrence A. Ptaff and associates which reveals that women are rated as better than men. Organizations should focus on women in their enterprise because women are interested in creating relationship. They focus on connection and responsibilities. Organization must understand in this changing era that men and women are different. Women 1.0 opportunity kit is given by Tom Peters where women's initiative is aimed at Enterprise Re-invention where reconsideration of practices are to be done such as hiring, reward system, promotion, vision, leadership etc.

\section{Chapter 13: Little Things Are The Only Things}

There are so many opportunities that are available to organizations and "Design" is one of them. Little things create big differences and lead organizations to the success. Successful organizations win by Design. According to Robert Hayes, Professor, Harvard Business School that tomorrow companies will compete on Design. Design is a mildly under heralded. Organizations such as body shop, NIKE, Gillette, Stanley and Braun 
dedicate themselves seriously to the products and services they produce. Design is the advantage for a small but very impressive number of companies. Design helps in differentiation.

Peters talks about "Design Mindfulness" which means when design becomes a core competence, Design Mindfulness persuades all aspects of an enterprise. One has to keep in mind that Design is actually risky. The goal of having great Design is the shock of recognition. In short, the bottom-line of this chapter is that:

\section{Chapter 14: Love All, Serve All}

\section{Innovation comes from design and Design is everything.}

In this chapter Tom Peters has described the good business strategy of Credo, Hard Roch cafe who says "love all, serve all". The main idea of this chapter is that "Great service is the greatest Innovation". Most of the companies focus on other things but don't focus on "Service" which is a best kept secret nominee. Organizations should consider and remember that customers don't need anything anymore but service". Competitive advantage is based on service. Companies are not considered loyal if they compete on quality or style. It's their service that makes them loyal. Awesome service is key to Innovation. Ritz- Carlton, a hotel is loyal to provide service. "Ritz Pause" that takes a couple of seconds for employee to stop and look in the customer's eyes and ask "How is everything going? Is there anything I can do for you?" is a small thing but it creates a big difference and its impact is huge and is a great service.

Customer service is a limited concept. One should emphasize on the ownership experience. Southwest Airlines has got spirited employees of over 20,000 who focus on providing quality services to its customers. Companies should hire, reward and promote customer obsessed folks just like Southwest Airlines. Service excellence is more than consistency, it's about surprise. Ritz Carlton, Disney, Southwest are special because they clearly, continually and consistently providing surprises.

\section{Chapter 15: We're Here To Live Life Out Loud}

\section{Great service is the greatest Innovation}

In the last chapter of the book, Tom Peters is of the view that we are here in the world to live life out loud. Innovation demands passion. Without passion, nothing can be achieved in business world. The passion leads you to the innovation in business. Passion demands obsession, enthusiasm, people and truth. Without these traits, passion is nothing. Passion demands people. People stuff is the only real stuff. The one who has passion in the business will have the guts, the nerve; the persistence to live his life as loudly as these very loud times demands. Leader is a dispenser of enthusiasm.

\section{Analysis of the book}

Although very practical examples from business world have been used in this book but after reading this book, one comes to know that unfortunately a few of such businesses don't exist now which creates chaos in the minds of readers. Furthermore, the same idea of innovation has been covered by some recent and older books which focus on hiring the talented HR, maintaining a good system and establishing branding. However, the idea of 
bringing innovation to the business by hiring women and establishing the PSF Kit is something that is totally new and novel for the readers. Tom Peters has given justice to the material with his creative writing style that is easy to understand. This book should be taught to the management students so as to guide and help them out knowing the basic concepts of Innovation and the strategies that should be devised and adopted by businesses in order to rule the business world by capturing the largest market share. This book is recommended to the entrepreneurs and inventors who will learn the basic tactics of how to bring innovation in the overall business.

"If everything seems under control, you're not going fast enough."

Mario Andretti, race car driver

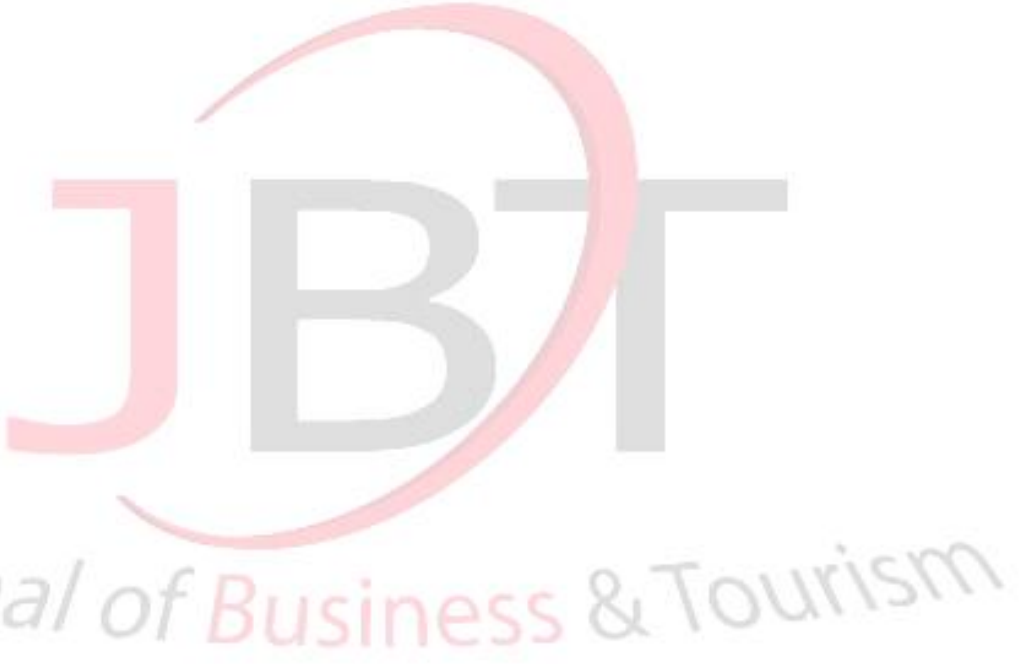

